\title{
Preparation and Characterization of Zinc-substituted Bioactive Glasses with Sol-gel Method
}

\author{
K. M. Tohamy, A. S. Abd Raboh" and A. G. Mostafa" \\ Biophysics Branch and *Physics Department, Faculty of Science, \\ Al-Azhar University, Nasr City, Cairo, Egypt.
}

\begin{abstract}
N PRESENT study, Different bioactive glass samples are prepared based on the following general formula: $\left[65 \% \mathrm{SiO}_{2}-(25-\mathrm{X}) \% \mathrm{CaO}\right.$ $\left.\left.10 \% \mathrm{P}_{2} \mathrm{O}_{5}-\mathrm{X} \% \mathrm{ZnO}\right)\right] ; \mathrm{Ca}^{2+}$ is gradually substituted with $\mathrm{Zn}^{2+}$ (percentages of $\mathrm{X}=0,2,4,6,8$ and $10 \mathrm{~mol} \%$ ) by a quick alkalimediated sol-gel method. Development of a calcium phosphate (CP) layer on their surfaces is studied by soaking them in a simulated body fluid (SBF) for different periods. The consequent formation of the $\mathrm{CP}$ layer is studied by means of appropriate techniques such as X-ray diffractometry (XRD), Fourier transform infrared (FTIR) spectroscopy and scanning electron microscopy (SEM) with an energy dispersive system (EDXS). The concentration of $\mathrm{Ca}^{2+}, \mathrm{P}^{5+}$ ions released from the samples into the SBF is measured by using UV-Vis Spectrophotometer and biochemical Kits. The results show that the formation of calcium phosphate layer on glass surfaces is inhibited by $\mathrm{ZnO}$ substitution, and strongly dependent on $\mathrm{Zn}^{2+}$ concentration.
\end{abstract}

Since the discovery of the first bioglass by Hench et al. ${ }^{(1)}$. several other glass compositions have been imposed to improve the rehabilitation process in surgical applications. One of the important trends in recent studies is incorporation of some ions in the bioglass composition to improve its biofunctionallity. Regarding the stimulatory effects of some cations such as $\mathrm{Mg}^{2+}, \mathrm{Sr}^{2+}$ and $\mathrm{Zn}^{2+}$ on bone formation either by oral administration or local delivering process ${ }^{(2)}$, the effect of incorporation of these ions on the physical and physicochemical properties of sol-gel derived glasses has been reported.

Zinc $(\mathrm{Zn})$ is the second most prevalent trace element in the human body and is reported to stimulate fracture healing of bone ${ }^{(3)}$, reduces postmenopausal bone loss ${ }^{(4)}$, improves bone mineralization ${ }^{(5)}$, and improves skeletal strength ${ }^{(6)}$. Furthermore, $\mathrm{Zn}$ is an effective agent in killing bacterial strains commonly associated with infection in orthopedic surgeries ${ }^{(7)}$.

Despite the numerous works reporting the stimulating effects of zinc, there are also studies that show other effects of zinc ions on bone cells. Popp et al. studied the effect of $\mathrm{Zn}^{2+}$-supplemented osteogenic medium on osteoblastic

${ }^{\#}$ Contact co-author email: ahmed1118343@yahoo.com 
proliferation and differentiation. They used concentrations of $0.20,0.65$ and $2.62 \mathrm{mg} / \mathrm{l}$ and found no significant effects of such zinc amounts on rat bone marrow stromal cells ${ }^{(8)}$. The use of synthetic bone substitutes for delivery of zinc ions has recently gained attention in research communities. There are numerous studies regarding the development and evaluation of zinc-containing calcium phosphate ceramics both in vitro and in vivo ${ }^{(9-13)}$. There are also reports concerning the use of different bioactive glass compositions as short- or longterm zinc delivery vehicles ${ }^{(14-17)}$. Bioactive glass, due to its osteostimulative and bone bonding properties, has been successfully used clinically in dental, craniomaxillofacial and spinal applications during the last few decades. Its bonebonding ability arises from the high rate of formation of hydroxyl-carbonate apatite (HCA) at the surface of the material after reaction with the surrounding biological fluids. The bone-like, low-crystalline HCA, together with the ionic products resulting from the degradation process of the material, are also correlated to the intrinsic and characteristic bioactive glass bone regeneration potential. They have been shown to be responsible for enhancing the proliferation and differentiation of osteoprogenitor cells ${ }^{(17)}$.

A variety of sol-gel-derived bioglass materials incorporating modifiers such as magnesium, cerium, boron, strontium and calcium have been reported with the aim of improving specific characteristics. The possibility of incorporating zinc into bioglasses has received special interest in recent years due to the potential benefits of such a glass ${ }^{(18)}$. However, the formation of zinc containing bioglasses and their properties and characteristics does not seem to have been well explored. Zinc as an essential trace element is known to have stimulatory effects on bone formation in vitro and in vivo ${ }^{(19-20)}$. The beneficial features of zinc have stimulated our current interest in zinc-containing bioglasses described herein.

The present study investigates the effect of zinc substitution for calcium on bioactivity of sol-gel derived $\mathrm{Zn}$-containing glasses. Prepare six different bioactive glass samples composed of $\left.\left.65 \mathrm{SiO}_{2}-(25-\mathrm{x})-\mathrm{CaO}-10 \mathrm{P}_{2} \mathrm{O}_{5}-(\mathrm{x}) \mathrm{ZnO}\right)\right], \mathrm{Ca}$ was gradually substituted with Zn (percentages of $0,2,4,6,8$ and 10) by sol-gel method. Samples characterized by using different techniques (DSC), XRD, FTIR, (DSC) and (EDX). Study the resorbability and dissolution of prepared samples in physiological fluid which simulate the body fluid SBF and perform some spectrophotometer analysis using biochemical Kits.

\section{Samples preparation}

\section{Materials and Methods}

Chemical composition of the bioactive glasses along with the code of each composition is presented in Table 1 . The glass composition $\left(65 \% \mathrm{SiO}_{2}, 25 \%\right.$ $\mathrm{CaO}, 10 \% \mathrm{P}_{2} \mathrm{O}_{5}$, mol\%) named $\mathrm{Zn}(0)$ was used as a control sample and $\mathrm{CaO}$ was gradually replaced with $\mathrm{ZnO}$ in its composition. glass of composition $\mathrm{SiO}_{2}$ $\mathrm{P}_{2} \mathrm{O}_{5}-\mathrm{CaO}-\mathrm{ZnO}$ was prepared using stoichiometric amount of precursors and the gels were obtained with a quick alkali-mediated sol-gel method as described previously ${ }^{(21)}$. Initially, tetraethoxysilane $\left(\mathrm{Si}\left(\mathrm{OC}_{2} \mathrm{H}_{5}\right)_{4}\right)$, (TEOS; Sigma-Aldrich) was added to $0.1 \mathrm{M}$ nitric acid and the mixture was allowed to react for $60 \mathrm{~min}$

Egypt. J. Biophys. Biomed. Engng. Vol. 16 (2015) 
for the acid hydrolysis of TEOS. Then a series of reagents was added in the following sequence, allowing $45 \mathrm{~min}$ for each reagent to react completely: triethylphosphate $\left(\mathrm{PO}\left(\mathrm{OC}_{2} \mathrm{H}_{5}\right)_{3}\right)$ (TEP; Sigma-Aldrich), calcium nitrate tetra hydrate $\mathrm{Ca}\left(\mathrm{NO}_{3}\right)_{2} \cdot 4 \mathrm{H}_{2} \mathrm{O}$ (Sigma-Aldrich) and strontium nitrate $\mathrm{Zn}\left(\mathrm{NO}_{3}\right)_{2}$ (Sigma-Aldrich). After the final addition, mixing was continued for $1 \mathrm{~h}$ to allow the completion of hydrolysis. The $\mathrm{Zn}$-free bioglass $\mathrm{SiO}_{2}-\mathrm{P}_{2} \mathrm{O}_{5}-\mathrm{CaO}\left(65 \% \mathrm{SiO}_{2}\right.$, $25 \% \mathrm{CaO}, 10 \% \mathrm{P}_{2} \mathrm{O}_{5}$, mol \%) was also synthesized by the same procedure to compare its bioactivity with that of the $\mathrm{Zn}$-substituted bioglass. $\mathrm{NH}_{4} \mathrm{OH}$ added to the resulted solution for gelation. The resultant gel was kept in a sealed container and heated at $70{ }^{\circ} \mathrm{C}$ for an additional 3 days. The water was removed and a small hole was inserted in the lid to allow the leakage of gases while the gel was heated to $120^{\circ} \mathrm{C}$ for 2 days to remove all the free water. The dried gel was then heated for $24 \mathrm{~h}$ at $600{ }^{\circ} \mathrm{C}$ to stabilize the glass and eliminate residual nitrates.

TABLE 1. Chemical composition of investigated glass samples (in mol \%).

\begin{tabular}{|c|c|c|c|c|}
\hline Glass code & $\mathbf{S i O}_{\mathbf{2}}$ & $\mathbf{C a O}$ & $\mathbf{P}_{\mathbf{2}} \mathbf{O}_{\mathbf{5}}$ & $\mathbf{Z n O}$ \\
\hline $\mathrm{Zn}(0)$ & 65 & 25 & 10 & 0 \\
\hline $\mathrm{Zn}(2)$ & 65 & 23 & 10 & 2 \\
\hline $\mathrm{Zn}(4)$ & 65 & 21 & 10 & 4 \\
\hline $\operatorname{Zn}(6)$ & 65 & 19 & 10 & 6 \\
\hline $\operatorname{Zn}(8)$ & 65 & 17 & 10 & 8 \\
\hline $\operatorname{Zn}(10)$ & 65 & 15 & 10 & 10 \\
\hline
\end{tabular}

\section{Characterization techniques}

The DSC/ TG characterization of the dried gel was conducted in Differential Scanning Calorimeter (DSC) [computerized SETARAM labsys ${ }^{\mathrm{TM}}$ ] Thermal Analyser. The sample was heated in flowing Argon gas atmosphere at a heating rate of $10^{\circ} \mathrm{C} / \mathrm{min}$. The weight loss measurements were also done in the same instrument and both the graphs were merged into one for comparative analysis. Phase analysis of the samples was examined by X-ray diffractometer (XRD); model BRUKER axs, using Ni-filtered $\mathrm{CuK} \alpha$ irradiation at $40 \mathrm{kV}$ and $25 \mathrm{~mA}$. FTIR absorption spectra were recorded at room temperature in the $400-4000$ $\mathrm{cm}^{-1}$ range using a spectrometer of type (FT-IR-400, JASCO, Japan). The obtained spectra were used to analyze the structure of glasses before and after immersion in the simulated body fluid (SBF).

Morphological observation of the resultant glasses was performed by Philips XL 30 scanning electron microscope (SEM) with an accelerating voltage of $30 \mathrm{kV}$. Specimens were placed on a stub using a carbon sticker and examined under the microscope after being sputtered with a thin coat of gold. Elemental image analysis was also carried out using energy dispersive X-ray analysis ((EDXA; $30 \mathrm{~mm} 2 \mathrm{Si}$ (Li) R-RSUTW detector)) coupled to the SEM instrument. EDX used to compare the intensities of calcium $(\mathrm{Ca})$, phosphor $(\mathrm{P})$ in bioglass before and after immersion in $\mathrm{SBF}$. The changes in concentration of $\mathrm{Ca}, \mathrm{P}$ of the extracted SBF solution were measured by UV-Vis (Jenway) Spectrophotometer technique. 
In vitro bioactivity analysis

Immersion in SBF

Hydroxyl apatite forming ability of the bioglass disks was analyzed by immersing the samples in simulated body fluid (SBF) for periods of time. Each specimen was immersed in Tris-buffered SBF solution with ion concentrations and $\mathrm{pH}$ nearly equal to that of human blood plasma (Table 2) at $37 \pm 0.5^{\circ} \mathrm{C}$, for 21 days. A surface area to volume ratio of $0.1 \mathrm{~cm}^{-1}$ was maintained for all immersions, and the SBF solutions were not exchanged during the experiments.

TABLE 2. Concentration (mM) and pH of simulated body fluid (SBF) and human plasma $^{(23)}$.

\begin{tabular}{|c|c|c|}
\hline Ion & $\begin{array}{c}\text { SBF } \\
\text { (mM concentration) }\end{array}$ & $\begin{array}{c}\text { Plasma } \\
(\mathbf{m M} \text { concentration) }\end{array}$ \\
\hline $\mathrm{Na}^{+}$ & 142 & 142 \\
\hline $\mathrm{K}^{+}$ & 5.0 & 5.0 \\
\hline $\mathrm{Mg}^{++}$ & 1.5 & 1.5 \\
\hline $\mathrm{Ca}^{++}$ & 2.5 & 2.5 \\
\hline $\mathrm{C}^{1-}$ & 147.8 & 103.0 \\
\hline $\mathrm{HCO}_{3}{ }^{-}$ & 4.2 & 4.2 \\
\hline $\mathrm{HPO}_{4}^{--}$ & 1.0 & 1.0 \\
\hline $\mathrm{SO}_{4}{ }^{2-}$ & 0.5 & 0.5 \\
\hline $\mathrm{pH}$ & 7.25 & $7.20-7.40$ \\
\hline
\end{tabular}

The SBF was prepare by dissolving reagent-grade $\mathrm{NaCl}, \mathrm{NaHCO}_{3}, \mathrm{KCl}$, $\mathrm{K}_{2} \mathrm{HPO}_{4}, 3 \mathrm{H}_{2} \mathrm{O}, \mathrm{MgCl}_{2}, 6 \mathrm{H}_{2} \mathrm{O}, \mathrm{CaCl}_{2}$, and $\mathrm{Na}_{2} \mathrm{SO}_{4}$ in deionized water. The solution was buffered to $\mathrm{pH} 7.4$ with Tris-(hydroxymethyl)-aminomethane $\left(\left(\mathrm{CH}_{2} \mathrm{OH}\right)_{3} \mathrm{CNH}_{3}\right)$ and hydrochloric acid ${ }^{(22)}$. The samples were removed from the incubator, rinsed gently, first with pure ethanol and then using deionized water, and left to dry at ambient temperature in desiccators for $3 \mathrm{~h}$.

Changes in phase composition of the specimens were determined by X-ray diffractometry (XRD). After 21 days of soaking in SBF, the samples were withdrawn from the solution and washed with distilled water, dried at room temperature, ground to fine powder and analyzed. XRD has been made for all samples with Co K $\alpha(1.54 \AA)$ radiation, identified by JCPDS International Center for Diffraction Data Cards. The patterns of unsoaked bioactive glass specimens were also taken for comparison.

FTIR spectra of the bioactive glasses were measured at room temperature in the wave number range of $4000-400 \mathrm{~cm}^{-1}$ using a Fourier transform infrared spectrometer (Shimadzu (Japan) FTIR-8700). Fine powders were mixed with $\mathrm{KBr}$

Egypt. J. Biophys. Biomed. Engng. Vol. 16 (2015) 
powder by the ratio of 1:100. The FTIR spectra were immediately measured after preparation of the disc. The obtained spectra were used to analyze the structure of glasses before and after immersion in the simulated body fluid (SBF).

Change in concentration of $\mathrm{Ca}, \mathrm{P}$ ions of the $\mathrm{SBF}$ was measured soaking the powder samples in $80 \mathrm{ml}$ of SBF in polyethylene containers maintained at $37{ }^{\circ} \mathrm{C}$ for 21 days. During the course of immersion the dissolution of $\mathrm{Ca}$ and $\mathrm{P}$ ions into the SBF solution was monitored periodically using UV-Vis spectrophotometer technique.

\section{Results and Discussion}

\section{DSC and TGA thermal analysis}

DSC-TG curves of $\mathrm{SiO}_{2}-\mathrm{CaO}-\mathrm{P}_{2} \mathrm{O}_{5}-\mathrm{ZnO}$ powder heated up to $1000{ }^{\circ} \mathrm{C}$ are shown in Fig .1. The total weight loss shown in TG curve is about $36 \mathrm{wt} \%$. The first weight loss occurred in the temperature range of $25-180{ }^{\circ} \mathrm{C}$ (less $2.5 \mathrm{wt} \%$ ) can be ascribed to the loss of alcohol and water. The second weight loss $(14.40 \mathrm{wt} \%)$ occurred in the range of $180-280^{\circ} \mathrm{C}$ is associated with the partial elimination of organic residues which is confirmed by the corresponding endothermic signal in the DSC curve. Very slow heating in this temperature range was very important to eliminate the remaining organics. More weight loss commenced from the end of first weight loss $\left(280{ }^{\circ} \mathrm{C}\right)$ up to $600{ }^{\circ} \mathrm{C}$, which is most likely due to the loss of organic material by further condensation. The maximum weight loss rate takes place between 300 and $500{ }^{\circ} \mathrm{C}$, thus the gels were further calcined at $500{ }^{\circ} \mathrm{C}$ to remove organic residuals; the weight loss above that may due to the elimination of hydroxyls. In general, the dried gels showed overall weight losses around 20-30\% over the temperature range $50-800{ }^{\circ} \mathrm{C}$ during the course of TGA measurements ${ }^{(24)}$.

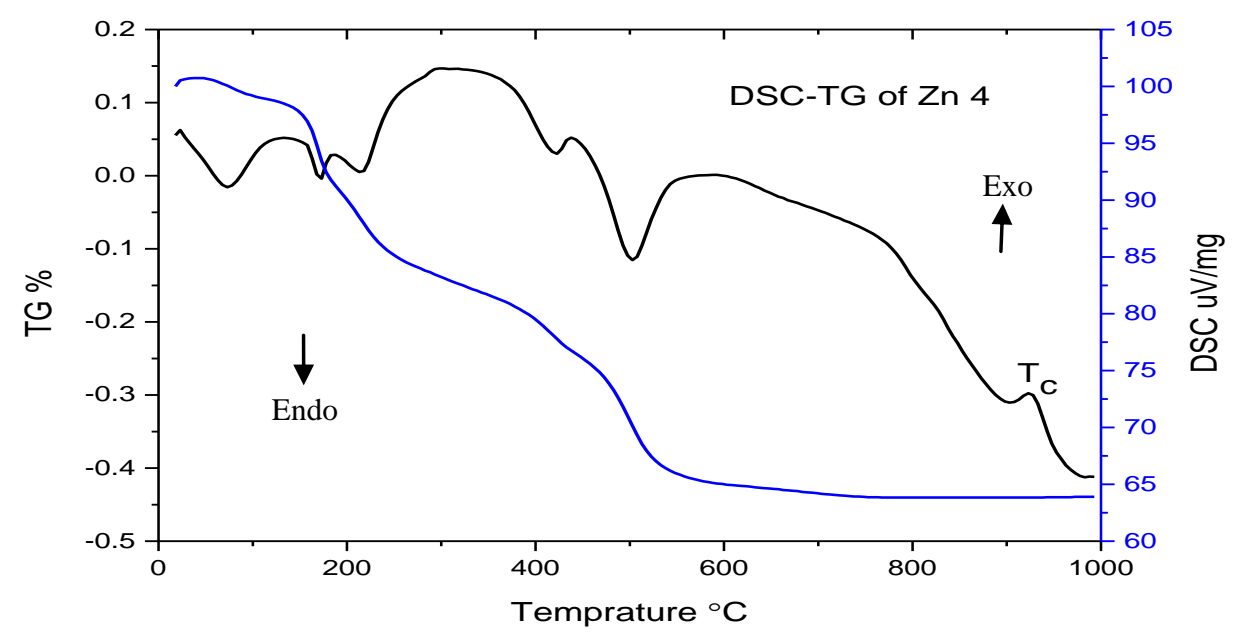

Fig. 1. DSC-TG curves of zinc containing glass $\mathrm{Zn}(4 \%)$.

Egypt. J. Biophys. Biomed. Engng. Vol. 16 (2015) 
DSC trace is a plot of heat changes of the glass as a function of temperature and is used to determine temperatures at which phase transitions or another thermal phenomenon occur. The first endothermic peak which initiated from room temperature to $180^{\circ} \mathrm{C}$ corresponds to the release of physically adsorbed water and the pore liquor (water and by-products from the polycondensation reaction) that were not removed during drying. Second endothermic peak observed in the range of $180-220^{\circ} \mathrm{C}$ is attributed to the loss of the residual solvent (water and ethanol). Third endothermic peak (onset at $421{ }^{\circ} \mathrm{C}$ ) was due to the condensation of silanol groups and the removal of nitrate groups that are usually eliminated in the thermal stabilization process. All nitrates were removed by $500{ }^{\circ} \mathrm{C}$. Also, the large exothermic peak corresponded to crystallization of the glasses is appeared at $927^{\circ} \mathrm{C}$ for $\mathrm{BG}-\mathrm{Zn}{ }^{(25)}$.

X-Ray diffraction

Phase compoitiosn

Figure 2 shows the XRD pattern of the glass samples containing various amounts of Zn before immersion in SBF. All samples were devoid the crystalline peaks and take amorphous state characterized by the broad diffraction bands centered at $\sim 25$ in $2 \theta$, indicate the internal disorder and glassy nature of these materials.

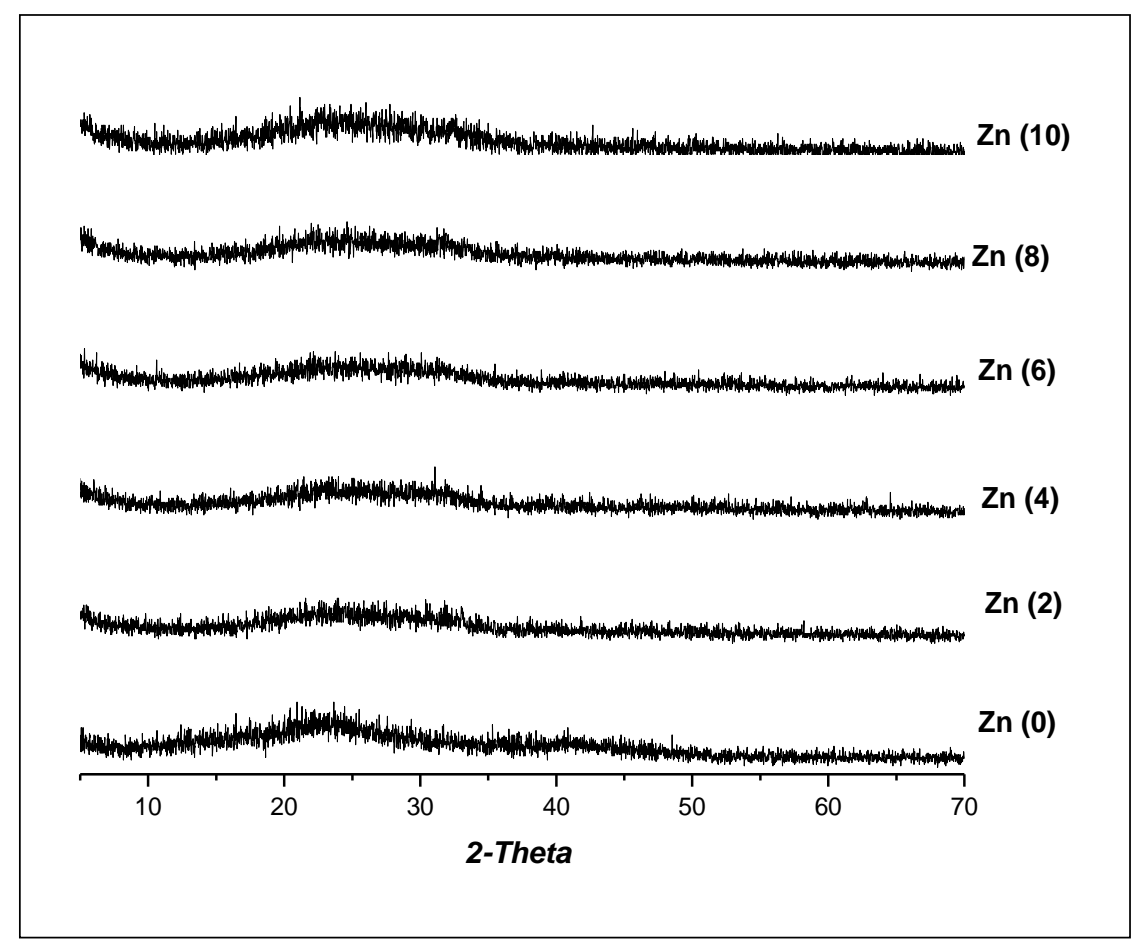

Fig .2. XRD pattern of the glass samples containing various amounts of $\mathrm{Zn}$ before immersion in SBF.

Egypt. J. Biophys. Biomed. Engng. Vol. 16 (2015) 
Figure 3. shows the XRD pattern of the glass samples containing various amounts of $\mathrm{Zn}$ after immersion in SBF. On immersion in SBF for 21 days, crystalline peaks appear in the XRD patterns, indicating the formation of a crystalline layer on the surface of the glass. Initially, two well-defined hydroxyl apatite (HA) peaks develop at $2 \theta$ values of $2 \theta=31.8^{\circ}(211)$ and $25.8^{\circ}(002)$ according to the standard JCPDS cards (76-0694). Wide diffraction peak at angles $(2 \theta)$ at $32.18^{\circ}, 32.8^{\circ}$ corresponds to the overlapping of $\left(\begin{array}{lll}1 & 1 & 2\end{array}\right),\left(\begin{array}{lll}3 & 0 & 0\end{array}\right)$ reflections of the well- crystallized HA. The XRD peak of the samples becomes broader, indicating lower crystallinity due to the addition of zinc. These changes suggest that the crystallinity of the apatite decreased as $\mathrm{Zn}$ fraction increase.

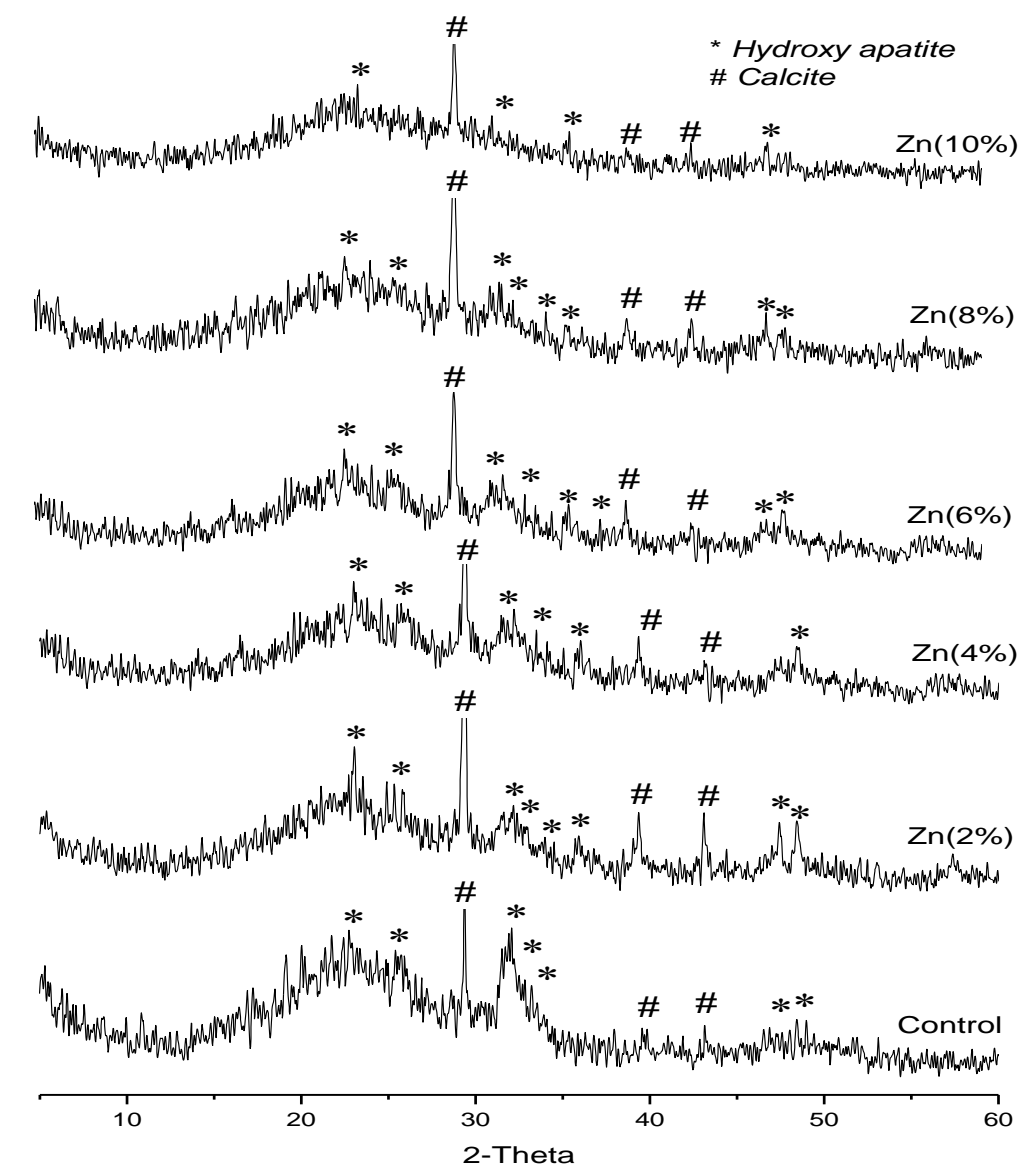

Fig. 3. XRD pattern of the glass samples containing various amounts of $\mathrm{Zn}$ after immersion in SBF for 21 days.

Egypt. J. Biophys. Biomed. Engng. Vol. 16 (2015) 
Calcite $\left(\mathrm{CaCO}_{3}\right)$ peaks: It is notable that in all samples there are two welldefined calcite $\left(\mathrm{Ca} \mathrm{CO}_{3}\right)$ peaks develop at $2 \theta$ values $29^{\circ}$ and $48^{\circ}$ according to the standard JCPDS cards (88-1809). Calcite peaks decreased gradually in other samples that contained higher amounts of zinc. Due to substitution of calcium with zinc content in glass composition, then amount of calcium ions that contributed in calcite formation decreased.

The mechanism of calcite phase formation is related to the release of high concentrations of calcium ion from glass to the SBF solution in the early stage of immersion. This high release of calcium and the presence of hydrogen carbonate ions in SBF allowed the precipitation of calcite following the reaction (1).

$$
\mathrm{Ca}_{2} \mathrm{O}+2 \mathrm{HCO}_{3}^{-} \rightarrow \mathrm{CaCO}_{3}+\mathrm{CO}_{2}+\mathrm{H}_{2} \mathrm{O}
$$

This fact confirms the hypothesis of a precipitation of calcium ions from glass with hydrogen carbonate ions when glass immersed in $\mathrm{SBF}^{(26)}$.

\section{Evaluation of crystallinity}

The degree of crystallinity $\left(\mathbf{X}_{\mathbf{C}}\right)$, corresponding to the fraction of crystalline phase present in the examined sample, was evaluated by the relation:

$$
X_{c}=1-\frac{V_{112 / 300}}{I_{300}}
$$

where : $\mathrm{I}$ is the intensity of the main peak reflection, $\mathrm{V}$ is the intensity of the hollow between the main peak and the peak beside it.

Determination of crystallites size by Scherer's equation

The crystallite size $(\mathbf{L})$ was calculated from: ${ }^{(27,28)}$

$$
L=\frac{\pi \lambda}{\beta \operatorname{Cos} \theta}
$$

where ( $\beta$ ) is the full width of the peak at half of maximum intensity (FWHM) (in radians), $(\lambda)$ is the wavelength of monochromatic X-ray beam $(\lambda=1.79026 \AA)$, $(\theta)$ is the diffraction angle, $(K)$ is a Scherer constant defined as the crystallite shape and is approximately equal 0.9 .

The formation of an apatite phase was confirmed by the observed HAP main peaks that appeared during the immersion. A broad band corresponding to the main apatite peak (2 11 1), (3 000$)$ and (2 000$)$ peaks appeared after 14 days.

Egypt. J. Biophys. Biomed. Engng. Vol. 16 (2015) 
As zinc concentration increases, the XRD peak of the samples become broader, indicating lower crystallinity due to the addition of zinc. Crystallinity, $\mathrm{Xc}$ is defined as the fraction of the crystalline phase in a sample volume. An empirical relation between $\mathrm{Xc}$ and $\beta$ is commonly deduced according to the Scherer's equation.

As the zinc content increased, both the crystallinity (Table 3) and crystal size (Table 4) decreased gradually. The ionic radius is smaller for $\mathrm{Zn}^{2+}(0.074 \mathrm{~nm})$ than that of $\mathrm{Ca}^{2+}(0.099 \mathrm{~nm})$, which might have distorted the crystal structure of hydroxyapatite. These changes suggest that the crystallinity of the apatite decreased as $\mathrm{Zn}$ fraction increase, which agree with the results of the XRD patterns. ${ }^{(29)}$

TABLE 3. The crystallinity $\left(X_{C}\right)(\%)$ of all samples.

\begin{tabular}{|c|c|c|c|}
\hline $\begin{array}{c}\text { Sample } \\
\text { code }\end{array}$ & I & V & $\begin{array}{c}\text { Crystallinity } \\
\left(\mathbf{X}_{\mathbf{c}}\right)\end{array}$ \\
\hline $\mathrm{Zn}(0)$ & 33 & 10 & 0.69 \\
\hline $\mathrm{Zn}(2)$ & 24 & 13 & 0.45 \\
\hline $\mathrm{Zn}(4)$ & 19 & 12 & 0.36 \\
\hline $\mathrm{Zn}(6)$ & 21 & 15 & 0.28 \\
\hline $\mathrm{Zn}(8)$ & 20 & 15 & 0.25 \\
\hline $\mathrm{Zn}(10)$ & 23 & 18 & 0.21 \\
\hline
\end{tabular}

TABLE 4. Crystal size of all samples.

\begin{tabular}{|c|c|c|c|c|c|}
\hline $\begin{array}{c}\text { Sample } \\
\text { code }\end{array}$ & $\mathbf{2 \theta}$ & $\boldsymbol{\theta}$ & $\mathbf{C o s} \boldsymbol{\theta}$ & $\boldsymbol{\beta}$ & $\begin{array}{c}\text { Crystal size } \\
(\mathbf{n m})\end{array}$ \\
\hline $\mathrm{Zn}(0)$ & 31.691 & 15.8455 & 0.962001 & 0.0086671 & 166.23 \\
\hline $\mathrm{Zn}(2)$ & 31.080 & 15.54 & 0.963443 & 0.013319 & 108.01 \\
\hline $\mathrm{Zn}(4)$ & 32.374 & 16.187 & 0.960356 & 0.013922 & 103.66 \\
\hline $\mathrm{Zn}(6)$ & 32.211 & 16.1055 & 0.960752 & 0.016726 & 86.25 \\
\hline $\mathrm{Zn}(8)$ & 32.117 & 16.0585 & 0.960979 & 0.064113 & 22.49 \\
\hline $\mathrm{Zn}(10)$ & 32.080 & 15.54 & 0.963443 & 0.092132 & 15.65 \\
\hline
\end{tabular}


Fourier transform infrared spectrometer (FTIR)

Before immersion

For all unsoaked glasses (Fig . 4), the bands appeared in the range 800-1100 $\mathrm{cm}^{-1}$ are ascribed to the stretching modes of $\mathrm{SiO}_{4}$ tetrahedra. The wide absorption band at $1000-1100 \mathrm{~cm}^{-1}$ assigned to the asymmetric stretching mode $\mathrm{Si}-\mathrm{O}$ (asym), the one weak band around $800 \mathrm{~cm}^{-1}$ is associated to symmetric stretching vibration $\mathrm{Si}-\mathrm{O}-\mathrm{Si}$ (sym). Furthermore, the band at $470 \mathrm{~cm}^{-1}$ can be ascribed to the $\mathrm{Si}-\mathrm{O}$ $\mathrm{Si}$ bending mode. The signals at around $1630,3433 \mathrm{~cm}^{-1}$ is also assigned to deformation mode of $\mathrm{H}-\mathrm{O}-\mathrm{H}$ group attributed to the absorbed water molecules.

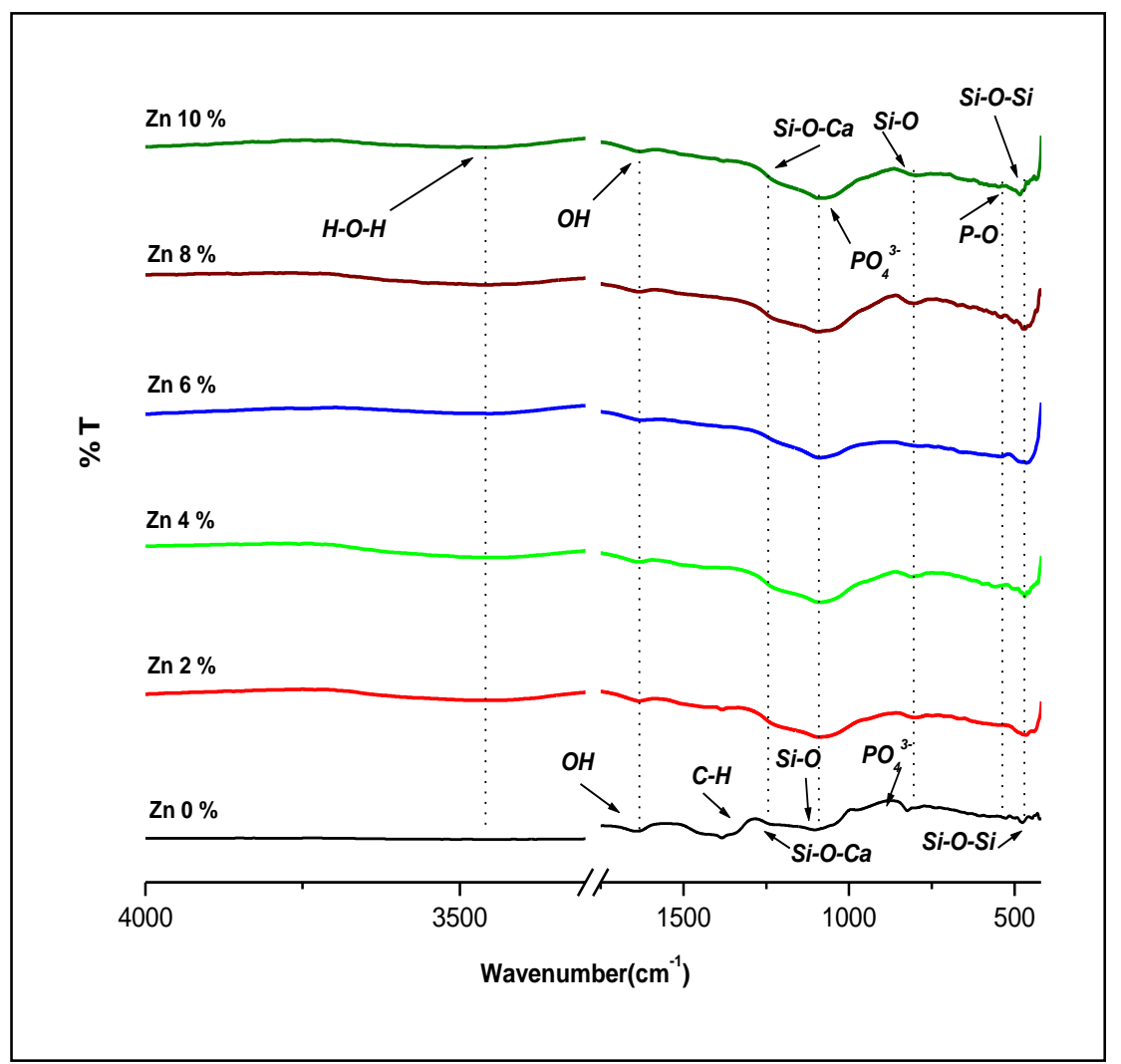

Fig. 4. FT-IR transmittance spectra for $\mathrm{Zn}$ containing glass before soaking in SBF .

\section{After immersion}

The sharpened bands in the range of $800-1100 \mathrm{~cm}^{-1}$ are probably due to the formation of silica gel like layer on the surfaces of these glasses (Fig 5). Peak at $562 \mathrm{~cm}^{-1}$ split into peaks at $570 \mathrm{~cm}^{-1}$ and $602 \mathrm{~cm}^{-1}$ which associated with the $\mathrm{P}-\mathrm{O}$ bending mode of crystalline phosphate group in HA structure. Shoulder appeared at $870 \mathrm{~cm}^{-1}$ is attributed to the stretching (str) mode of $\mathrm{C}-\mathrm{O}$ group in the lattice structure of the formed apatite layer. 


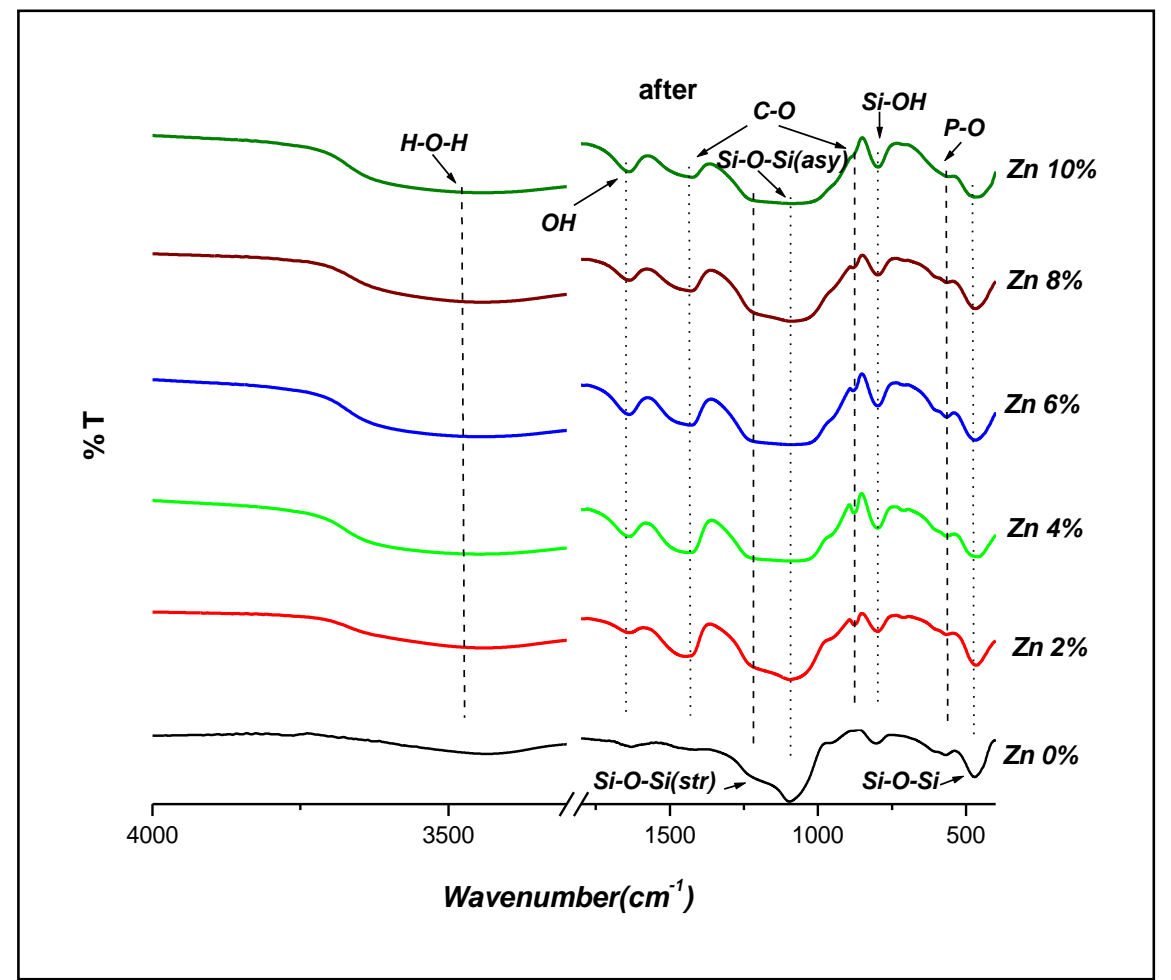

Fig.5. FT-IR transmittance spectra for Zn containing glass after soaking in SBF for 21 days.

The absorption band at around $1050 \mathrm{~cm}^{-1}$ associated with the $\mathrm{P}-\mathrm{O}$ stretching has an overlap with $\mathrm{Si-O}-\mathrm{Si}$ (asy) and thus is not clearly distinguishable. The shoulder in all samples at $1246 \mathrm{~cm}^{-1}$ is related to the non bridging oxygen bonds (NBO) of Si-O-Ca. Two bands located at 1620 and $3423 \mathrm{~cm}^{-1}$. These absorptions are characteristic of the presence of water related to the hygroscopic feature of the formed apatite. The bands that appeared at 875 and 1422 are assigned to $\mathrm{C}-\mathrm{O}$ stretching in carbonate groups substituted for phosphate groups in apatite lattice. ${ }^{(25)}$.

The band seen at $965 \mathrm{~cm}^{-1}$, can be related to the $\mathrm{Si}-\mathrm{O}-\mathrm{H}$ stretching vibration, this peak increases as the concentration of $\mathrm{Zn}$ decreases, which is expected since the peak of the silicon bonded to hydroxyl groups would be more intense. The band at around $800 \mathrm{~cm}^{-1}$ observed for all the considered concentrations, vary likely due to interaction between $\mathrm{Zn}^{+2}$ and the silica glass network which can result between the two characteristic bands for silica at $800 \mathrm{~cm}^{-1}$ and $470 \mathrm{~cm}^{-1}$. ${ }^{(30)}$. It is notable that the $\mathrm{ZnO}$ may be able to enter the forming apatite nuclei and thus inhibits their evolution to tiny apatite crystals. This can be considered for $\mathrm{ZnO}$ cannot be accommodated in the apatite structure (the apatite lattice) but changes in its physicochemical properties. ${ }^{(31)}$. 
Surface morphology and elemental composition

Figure 6 shows SEM -EDXS spectrum of the 4\% Zn-bioglass sample indicating the nominal composition of zinc substituted bioglass. . SEM of the glass surface revealed a heterogeneous surface with random-sized particles. EDXS spectrum show the presence of $\mathrm{Si}, \mathrm{P}, \mathrm{Zn}$ and $\mathrm{Ca}$ as the main elements of glass composition.
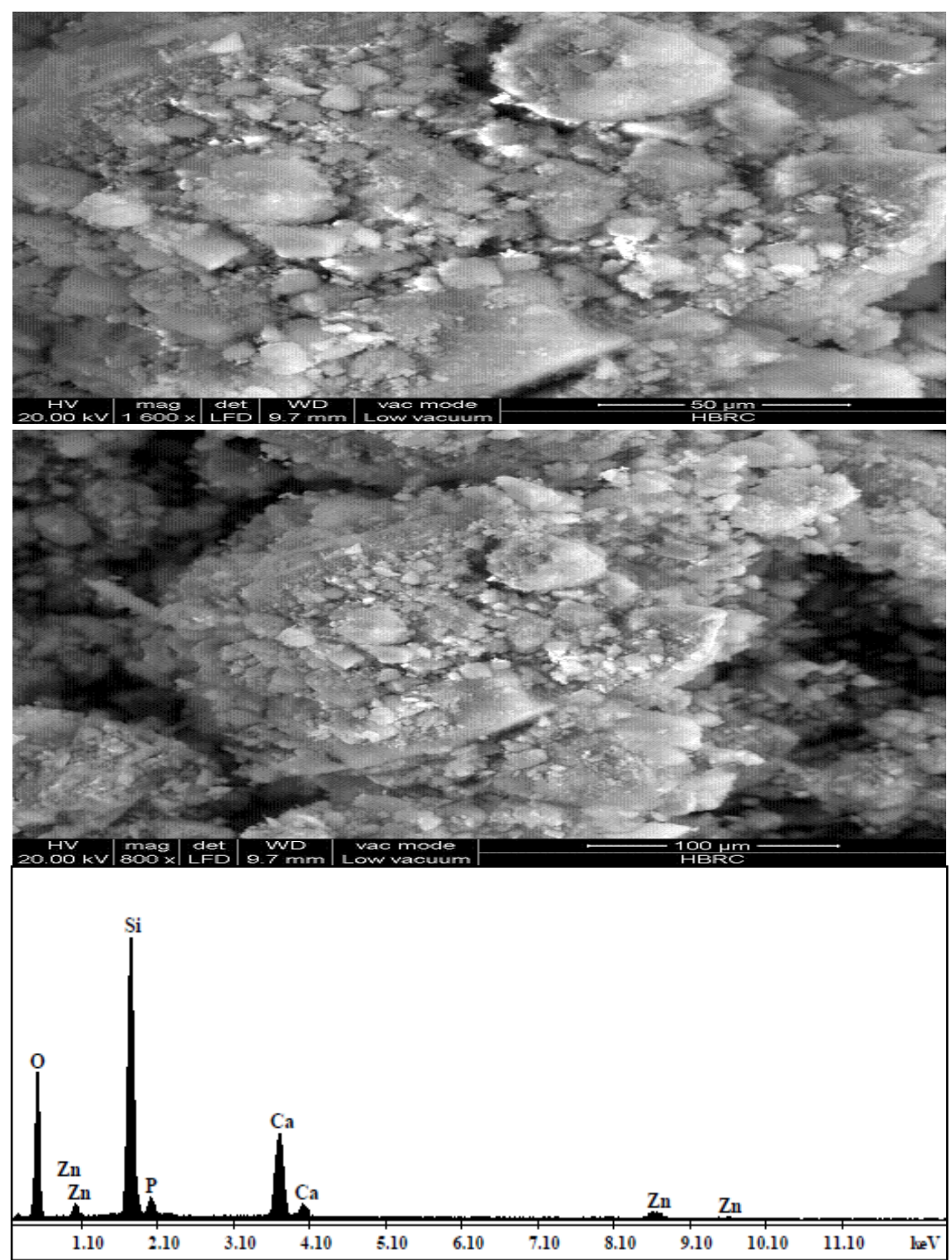

Fig. 6. SEM image -EDXS spectrum of the $4 \% \mathrm{Zn}$ bioglass system indicating the nominal composition and the heterogeneity nature of zinc substituted bioglass.

Egypt. J. Biophys. Biomed. Engng. Vol. 16 (2015) 
EDXA-SEM analysis of $4 \% \mathrm{Zn}$ bioglass system at the end of 21 days of immersion in SBF solution yielded important information about the formation of an appetite layer (Fig.7). The surface morphology of the glass sample shows the typical features of Ca-deficient apatite precipitation on the surface after immersion in SBF. High-magnification SEM images (Fig .7 upper) further reveal that each $\mathrm{Ca}-\mathrm{P}$ granule consists of a large number of tiny flake-like crystals of $\mathrm{Ca}-\mathrm{P}$ as reported earlier ${ }^{(33)}$. The bioglass specimens were further characterized in terms of their ability to form apatite in SBF. The elemental image analyses of $\mathrm{Zn} 4 \%$ sample carried out by EDS show the presence of $\mathrm{P}$ and $\mathrm{Ca}$ as the main elements of glass surface and confirm that the formed layers are calcium phosphate in nature.

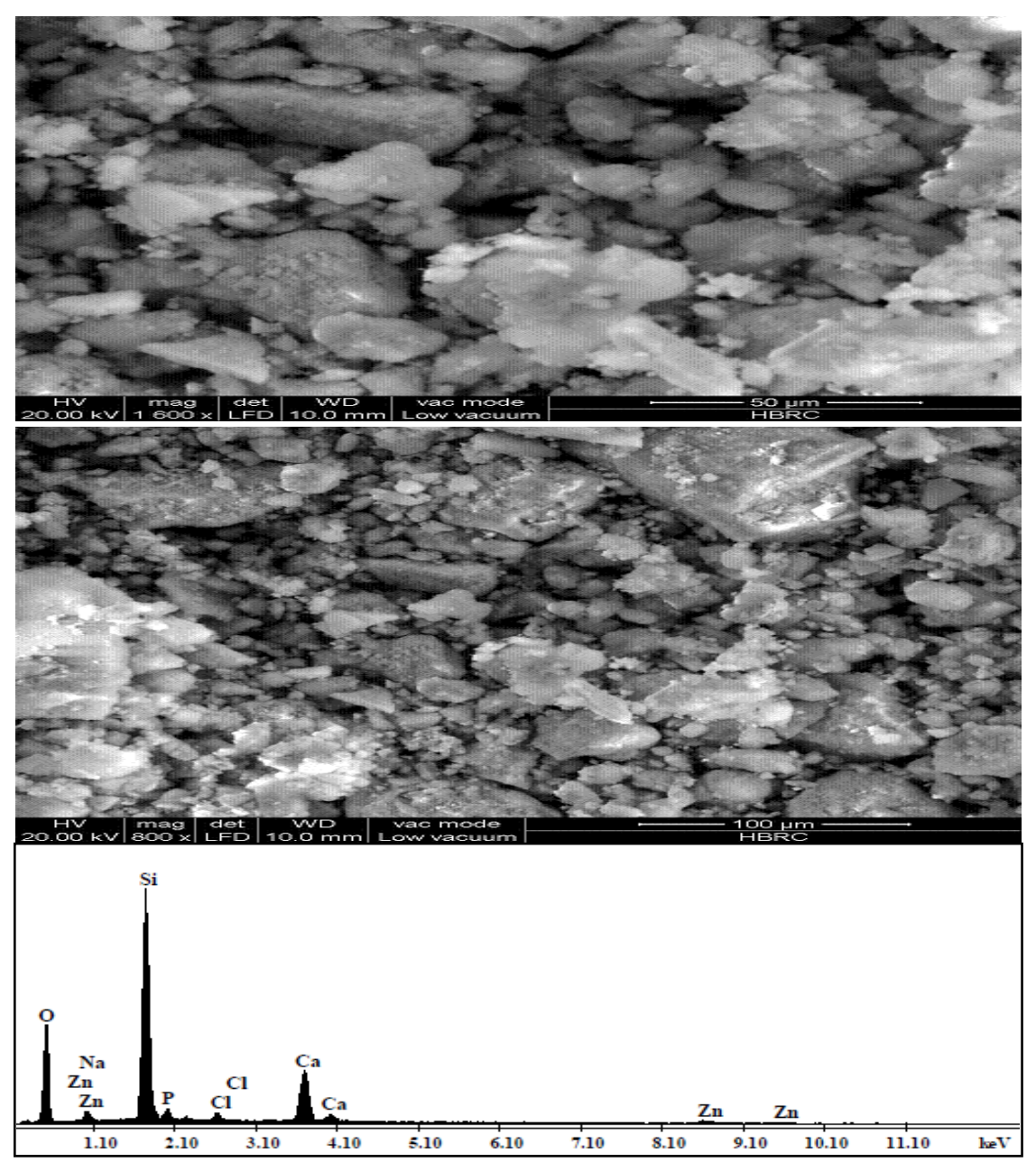

Fig. 7. SEM image - EDXS microanalysis of $4 \% \mathrm{Zn}$ bioglass surface after 21 days of immersion in SBF showing the significant increase in the ionic concentration of the apatite layer grown on the surface of the glass disk.

Egypt. J. Biophys. Biomed. Engng. Vol. 16 (2015) 
In BG-Zn specimen, although phosphorous is also found in its elemental composition, concentration of $\mathrm{Si}$ is considerable. The results suggest that a thin layer of calcium phosphate may be formed on Zn-containing glass which cannot be detected by XRD technique because of its low concentration with respect to the bulk volume. The appearance of $\mathrm{Si}$ element in EDS pattern of this specimen indicates the extenuation of the formed calcium phosphate layer. Also, peaks of $\mathrm{Cl}$ and $\mathrm{Na}$ suggests that these ions are incorporated into the crystal structure of apatite or adsorbed on glass surfaces from the SBF despite of washing process. ${ }^{(29)}$.

\section{Elemental analyses}

\section{Calcium concentration}

Figure 8 shows changes in $\mathrm{Ca}$ ions concentrations of SBF after soaking of the glasses. The change in concentration of $\mathrm{Ca}$ ions can reflect the competition condition between the rate of dissolution and precipitation processes. At $t=0$, concentration of calcium in SBF solution is approximately $100 \mathrm{mg} / \mathrm{L}$. The increase in the $\mathrm{Ca}$ concentration observed for all specimens at the end of first day is attributed to dissolution of the bioglasses phase. The $\mathrm{Ca}$ concentration higher than $100 \mathrm{mg} / \mathrm{L}$ means that the dissolution rate is faster than the precipitation rate and it is the opposite for the Ca concentrations lesser than $100 \mathrm{mg} / \mathrm{L}$.

The decrease in calcium concentration from 4 up to 15 day is due to the consumption of calcium ions through apatite formation on their surfaces.

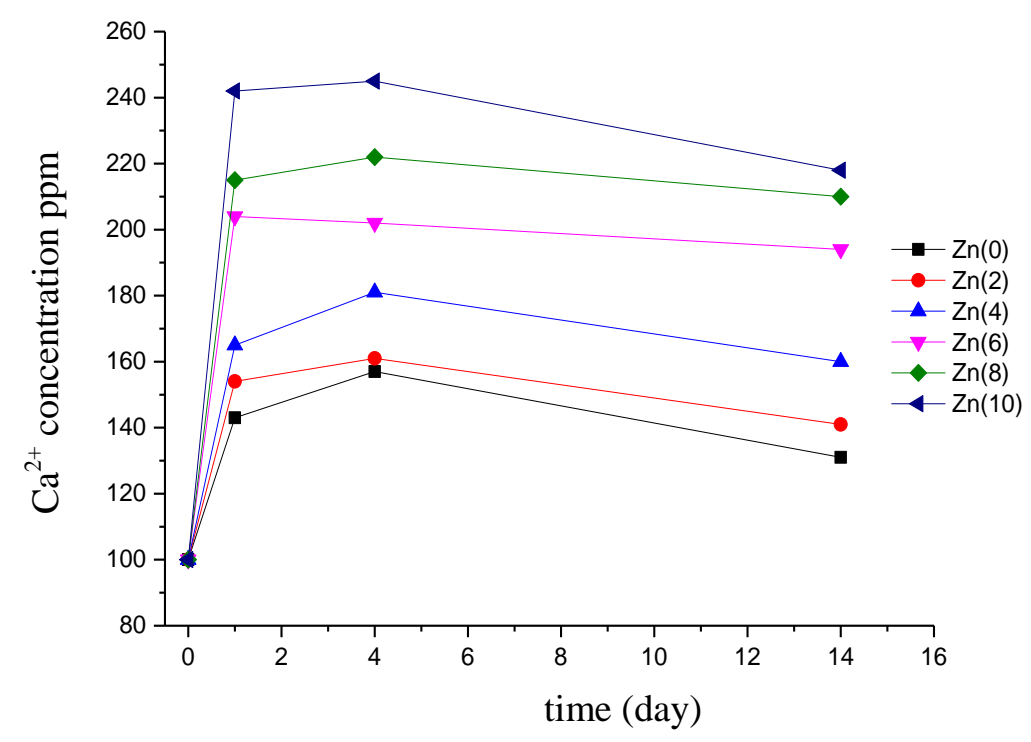

Fig. 8 . Concentration of $\mathrm{Ca}^{2+}$ ions in SBF for 15 days .

Egypt. J. Biophys. Biomed. Engng. Vol. 16 (2015) 


\section{Phosphorus concentration}

Figure 9 shows the concentration of $\mathrm{P}$ ions in SBF solution for 15 days of immersion. Before immersion phosphate ion concentration in SBF is 30ppm only. The phosphorus concentration increased with addition of zinc content, dissolution of (P) increased from first day up to fourth day, and then decreased gradually from 4 up to 15 day. This decrease in phosphorus concentration is due to the consumption of phosphate ions through the formation of apatite on the surfaces of glass samples Zn (0), Zn (2) Zn (4) and Zn (6).

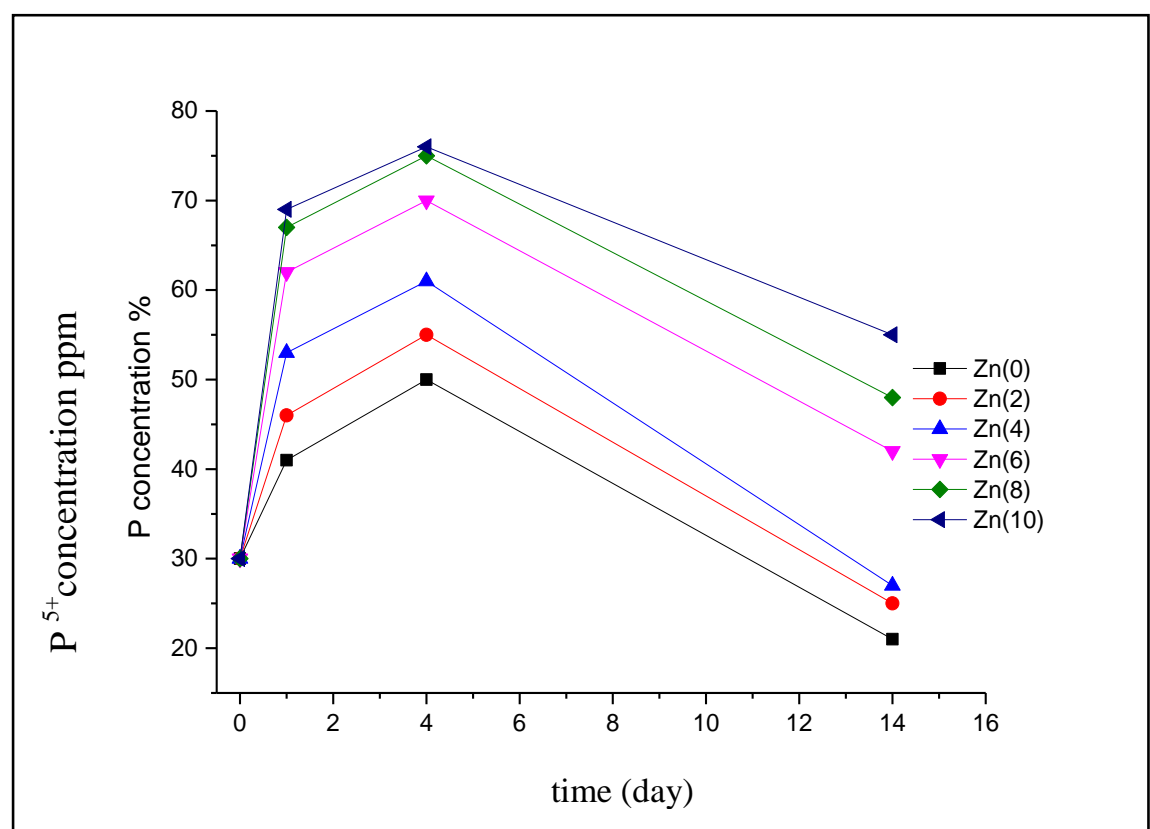

Fig. 9. Concentration of $\left(\mathrm{P}^{5+}\right)$ ions in SBF for 15 days.

\section{PH analysis}

The dissolution of $\mathrm{Ca}^{2+}$ ions from the samples would lead to locally increase of the $\mathrm{pH}$ value of the surrounding fluid as shown in Fig .10 that has a strong effect on the relative solubility of different phosphate phase, which should result in precipitation of new apatite crystals on the surface of the glass. However, only after 14 days of soaking, apatite agglomerates were observed on the surfaces and accompanying the decrease of $\mathrm{Ca}^{2+}$ concentration. Zinc element detected in the deposited agglomerates suggests that zinc can inhibit the apatite phase formation from the solution in the early stages of dissolving. The precipitation would change the super saturation of the surround solution and then cause the further dissolution of the samples. However, the $\mathrm{Ca}^{2+}$ concentration has not shown a fast increment with the increasing of soaking time after deposition of apatite agglomerates ${ }^{(33)}$. 


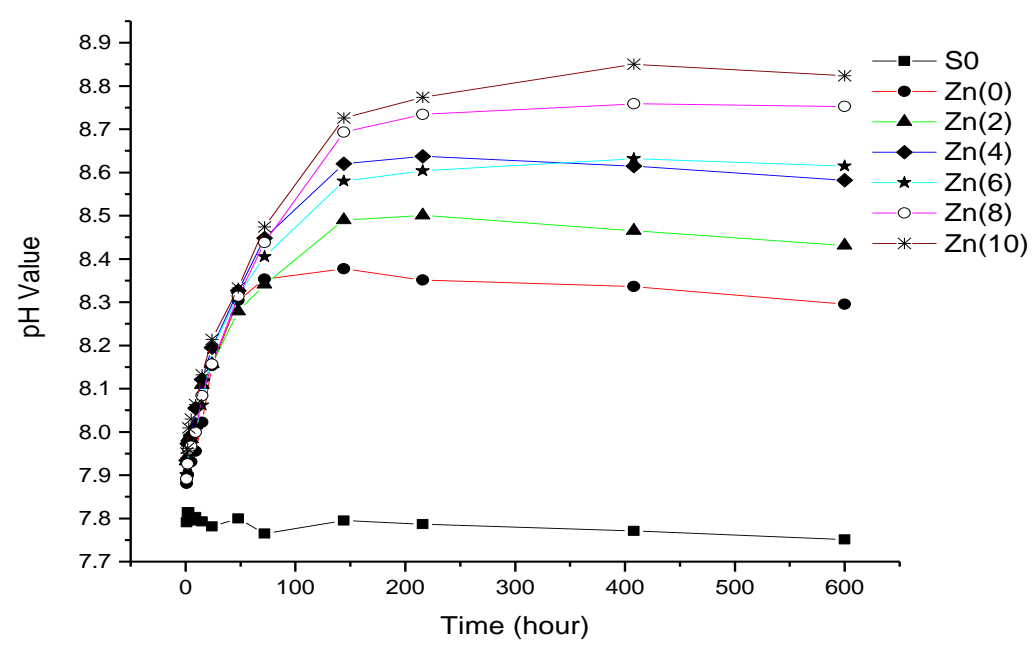

Fig. 10. The change in $\mathrm{pH}$ results of $\mathrm{Zn}$ containing bioglasses after immersion in SBF for 15 days.

\section{Conclusion}

Different bioactive glass samples were prepared composed of $\left[\mathrm{SiO}_{2}-\mathrm{CaO}\right.$ $\mathrm{P}_{2} \mathrm{O}_{5}-\mathrm{ZnO}$ )], Ca was gradually substituted with $\mathrm{Zn}$ (percentages of $0,2,4,6,8$ and $10 \mathrm{~mol} \%$ ) by sol-gel method. The results showed that Substitution of Ca with $\mathrm{Zn}$ ions in the glass composition decreased the solubility of the bioactive glass, and inhibit formation of calcium phosphate layer, strongly dependent on $\mathrm{Zn}$ concentration. $\mathrm{ZnO}$ addition reduces the reaction between the glass sample and surrounding body fluid. $\mathrm{ZnO}$ gives the glass the potential not only to control their reaction with body fluid, but also for enhanced bone formation. Crystal size and crystallinity of apatite peaks decreased gradually by addition zinc amount. SEM exhibit there is flake-like crystals seems that covered limited amount of the surfaces of (4\% ZnBG) bioglass sample. These flake-like crystals have been expressed that they are precipitated calcium phosphate with bone-like morphology.

\section{References}

1. Hench L., Splinte, J., Allen C., and Greenlee, K., Bonding mechanisms at the interface of ceramic prosthetic materials, J. Biomed. Mater. Res, 2 (Part I), 117-141 (1971).

2. Buehler, J., Chappuis, P., Saffar, J.L., Tsouderos, Y. and Vignery A., Strontium ranelate inhibits bone resorption while maintaining bone formation in alveolar bone in monkeys, Bone, 29, 176-179 (2001).

Egypt. J. Biophys. Biomed. Engng. Vol. 16 (2015) 
3. Igarashi, A. and Yamaguchi, M., Stimulatory effect of zinc acexamate administration on fracture healing of the femoral-diaphyseal tissues in rats, General Pharmacology, 32(4), 463-469 (1999).

4. Saltman, P.D. and Strause, L.G., The role of trace minerals in osteoporosis, Journal of the American College of Nutrition, 12(4), 84-389 (1993).

5. Yamaguchi, M., Oishi, H. and Suketa, Y., Stimulatory effect of zinc on boneformation in tissue-culture , Biochemical Pharmacology, 36(22), 4007-4012 (1987).

6. Ovesen, J., Moller-madsen, B., Thomsen, J.S., Danscher, G. and Mosekilde, L., The Positive effects of zinc on skeletal strength in growing rats, Bone, 29(6), 565-570 (2001).

7. Boyd, D., Li, H., Tanner, D.A., Towler, M.R. and Wall, G.J. The antibacterial effects of zinc ion migration from zinc based glass polyalkenoate cements, J. Mat. Sci. Mat. Med, 17, 489-494 (2005).

8. Popp, J.R., Love, BJ. and Goldstein, AS., Effect of soluble zinc on differentiation of osteoprogenitor cells, J. Biomed Mater Res. 81, 766-9 (2007).

9. Ikeuchi, M., Ito. A., Dohi, Y., Ohgushi, H., Shimaoka, H. and Yonemasu, K., Osteogenic differentiation of cultured rat and human bone marrow cells on the surface of zinc-releasing calcium phosphate ceramics, J Biomed Mater Res. 67, 1115-22 (2003).

10. Ito, A., Ojima, K., Naito, H., Ichinose, N. and Tateishi, T., Preparation, solubility, and cytocompatibility of zinc-releasing calcium phosphate ceramics. J. Biomed Mater Res. 50, 178-83 (2000).

11. Ishikawa, K., Miyamoto, Y. Yuasa, T., Ito, A., Nagayama, M. and Suzuki, K. Fabrication of $\mathrm{Zn}$ containing apatite cement and its initial evaluation using human osteoblastic cells, Biomaterials, 23, 423-8 (2002).

12. Kawamura, H., Ito, A., Miyakawa, S., Layrolle, P., Ojima, K. and Ichinose, N., Stimulatory effect of zinc-releasing calcium phosphate implant on bone formation in rabbit femora, J. Biomed Mater Res. 50, 184-90 (2000).

13. Kawamura, H., Ito, A., Muramatsu, T., Miyakawa, S., Ochiai, N. and Tateishi, T., Long-term implantation of zinc-releasing calcium phosphate ceramics in rabbit femora, J. Biomed Mater Res. 65, 468-74 (2003).

14. Aina, V., Perardi, A., Bergandi, L., Malavasi, G., Menabue, L. and Morterra, C., Cytotoxicity of zinc-containing bioactive glasses in contact with human osteoblasts, Chem Biol Interact, 167, 207-18 (2007).

15. Du, R.L., Chang, J., Ni, S.Y., Zhai, W.Y. and Wang, J.Y., Characterization and in vitro bioactivity of zinc-containing bioactive glass and glass-ceramics , J. Biomater Appl, 20, 341-60 (2006). 
16. Kamitakahara, M., Ohtsuki, C., Inada, H., Tanihara, M. and Miyazaki, T. Effect of $\mathrm{ZnO}$ addition on bioactive $\mathrm{CaO}-\mathrm{SiO}_{2}-\mathrm{P}_{2} \mathrm{O}_{5}-\mathrm{CaF}_{2}$ glass- ceramics containing apatite and wollastonite, Acta Biomater, 2, 467-71 (2006).

17. Lusvardi, G., Malavasi, G., Menabue, L., Menziani, M.C., Pedone, A. and Segre, U., Properties of zinc releasing surfaces for clinical applications, J. Biomater Appl. 22, 505-26 (2008).

18. Day, R.M. and Boccaccini, A.R. Effect of particulate bioactive glasses on human macrophages and monocytes in vitro, J. Biomed. Mater. Res. 73, 73-9 (2005).

19. WHO, expert committe on trace elements in human nutrition. WHO Tech Rep Ser, 532, 9-15 (1973).

20. Yamaguchi, M., Inamoto, K. and Suketa, Y., Effect of essential trace metals on bone metabolism in weanling rates: comparison with zinc and other metals action, Res. Exp. Med., 186, 337-42 (1986).

21. El-Gohary, M.I., Tohamy, K. M., El-Okr, M.M., Ali, A. F. and Soliman, I. E. "Influence of composition on the in-vitro bioactivity of bioglass prepared by a quick alkali-mediated sol-gel method, Nature and Science, 11(3) , 26-33 (2013).

22. Kokubo, T. and Takadama, H., How useful is SBF in predicting in vivo bone bioactivity, "Biomaterials", 27, 2907-15 (2006).

23. Fujibayashi, S., Neo, M., Kim, H.M., Kokubo, T. and Nakamura T., A comparative study between in vivo bone ingrowths and in vitro apatite formation on $\mathrm{Na}_{2} \mathrm{O}-\mathrm{CaO}-\mathrm{SiO}_{2}$ glasses, Biomaterials, 24,1349-1356 (2003).

24. Ailing, Li. and Dong, Qiu., Phytic acid derived bioactive $\mathrm{CaO}-\mathrm{P}_{2} \mathrm{O}_{5}-\mathrm{SiO}_{2}$ gelglasses, J. Mater Sci: Mater Med, 7, 4464 (2011).

25. Shahrabi, S., Hesaraki, S., Saeed, M. and Mina, K., Structural discrepancies and in vitro nanoapatite formation ability of sol-gel derived glasses doped with different bone stimulator ions, Ceramics International, 37 , 2737-2746 (2011).

26. Mami, M., Lucas-Girot, A., Oudadesse, H., Dorbez-Sridi, R. and Mezahi, F., Investigation of the surface reactivity of a sol-gel derived glass in the ternary system $\mathrm{SiO}_{2}-\mathrm{CaO}-\mathrm{P}_{2} \mathrm{O}_{5}$, Applied Surface Science, 254, 7386-7393 (2008).

27. Heijligers, H., Driessens, F. and Verbeeck, R. Lattice-parameters and cation distribution of solid-solutions of calcium and strontium hydroxyapatite, Calcified Tissue Int, 29(2), 127-31 (1979).

28. Cullity, B.D., Elements of X-ray Diffraction, Reading, M.A. Addison- Wesley (1959).

29. Devanand, G., Ramasamy, S. and Ramakrishnan, V., Investigations on zinc doped nanocrystalline hydroxyapatite, International, Journal of NanoScience and Nanotechnology, 2, 1-23 (2011). 
30. Castillo, S. J., Acosta, M. C. and Zayas, M.A., Formation of ZnO in or on glasses by using the sol-gel and chemical bath deposition techniques, Seas Transactions on Circuits and Systems, 9, 150-161 (2010).

31. Jie, Q., Kaili, L., Jipin, Z., Yifeng, S., Qin, L. and Jiang, C., Preparation of Macroporous Sol-Gel Bioglass Using PVA Particles as Pore Former, Journal of SolGel Science and Technology, 30, 49-61 (2004).

32. Zhang, Y., Mizuno, M., Yanagisawa, M. and Takadama, H., Bioactive behaviours of porous apatite- and wollastonite-containing glass ceramic in two kinds of simulated body fluid , J. Mater. Res., 18, 433-41 (2003).

33. Cai, S., Zhang, W.J., Xu, G.H., Li, J.Y., Wang, D.M. and Jiang W., Microstructural characteristics and crystallization of $\mathrm{CaO}-\mathrm{P}_{2} \mathrm{O}_{5}-\mathrm{Na}_{2} \mathrm{O}-\mathrm{ZnO}$ glass ceramics prepared by sol-gel method, Journal of Non-Crystalline Solids, 355, 273279 (2009).

(Received 26/3/2014;

accepted $16 / 3 / 2015$ ) 
بإستخدام طريقة السول - جيل ذات الوسط القلوى السريع تم تحضير عدد من عينات الزجاج

، الحيوى النشط فى النظام [65\%

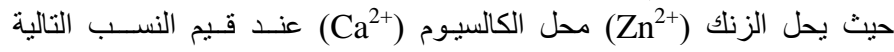

وذللك لتقييم النشاط الحيوي للعينات. تم غمر التر

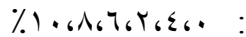

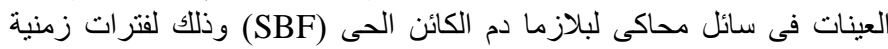

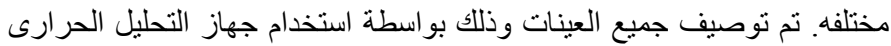

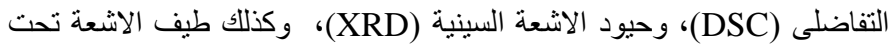

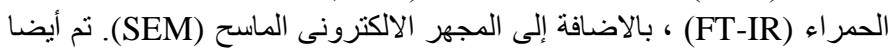

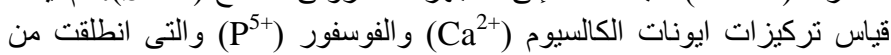

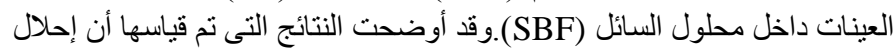

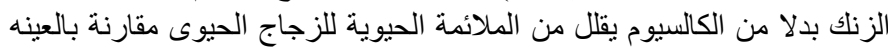

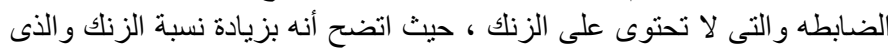

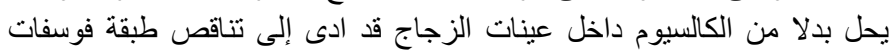

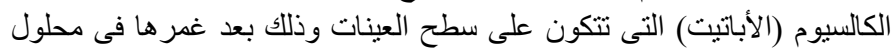

(SBF) 